\title{
Sports Medicine "Webliographies"
}

"Webliographies" are directories of web sites, used to locate information on the internet. Directories depend on people rather than software to update their information, so the sites they list are usually highly relevant. However, this relevancy is achieved at the expense of the completeness and currency achieved by search engines, which collect and update web sites automatically. Each directory also has different "views" of the internet, concentrating on different subject areas and geographical regions. Some directories just list sites, others have reviews or ratings to guide users to the best sites on the web. Below is a description of some of the major sports medicine webliographies.

Yahoo (www.yahoo.com or www.yahoo.co. uk) lists subjects hierarchically, and is searchable by keyword. The sports medicine section has two subsections, Diseases and Conditions (containing just athlete's foot and jock itch so far) and Institutes, as well as agenerallisting. Nerdworld (www.nerdworld. $\mathrm{com} / \mathrm{nw} 1822 . \mathrm{html}$ ) is another general index with a sports medicine section, items listed alphabetically with a short description of each site. To show how suprisingly little overlap there can be between directories, of 32 and 37 entries respectively at the time of writing, there are only four items common to both the above.

The NSMI web site has a links page (www.nsmi.org.uk/links.html) including national and international organisations, journals and publishers, universities running courses in sports medicine and sports science, as well as general sports medicine. MSPWEB (Medicine in Sport Pages on the Web) at www.mspweb.com is tightly focused on sports medicine and relatively comprehensive, each entry containing a short description. Items are grouped into broad categories, including organisations, clinics, and online journals. MedWeb Sports Medicine (www.gen.emory.edu/medweb/ medweb.sportsmed.html) is a large, searchable index that lists items in subject sections, for example, clinical practice, nutrition, news, and paediatrics, but with no descriptions. It isbroad inscope, also covering subjects such as medical products and occupational health. Stebbins' High School Hot Sports Medicine Links (www.geocities.com/ HotSprings/1190/links.htm) has a vast number of links (over 250), some rated, with many on general medicine as well as sports medicine. The Human Kinetics Physical Activity Links:Sports Medicine (www. humankinetics.com / infok / pal / sport.htm\# smed) is a concise list of sports medicine links, and includes details of email mailing lists and Human Kinetics titles. SportQUEST (www.sportquest.com) is a general sports links site, but being searchable, is good for finding medical information from sites devoted to individual sports. Medical Matrix (www.medmatrix.org/ Spages/Sports_Medicine.asp) has a short listing with a different focus to most sports medicine sites, as it doesn't include organisations' sites but lists forums, meetings, and published articles on the web. The entries are rated and listed in sections.

JAYNE MAKEPEACE

Visitors to the world wide web can now access the British fournal of Sports Medicine either through the BMJ Publishing Group's home page (http://www.bmjpg.com) or directly by using its individual URL (http:// www.bjsportmed.com). There they will find the following:

- Current contents list for the journal

- Contents lists of previous issues

- Members of the editorial board

- Information for subscribers

- Instructions for authors

- Details of reprint services

A hotlink gives access to:

- BMJ Publishing Group home page

- British Medical Association web site

- Online books catalogue

- BMJ Publishing Group books

The web site is at a preliminary stage and there are plans to develop it into a more sophisticated site. Suggestions from visitors about features they would like to see are welcomed. They can be left via the opening page of the BMJ Publishing Group site or, alternatively, via the journal page, through "about this site". 